Hatice KARAMAN

Faculty of Arts and Sciences, Yeditepe University

İstanbul, Turkey

hatice.karaman@yeditepe.edu.tr

\title{
RECONSIDERING THE WORLD REPUBLIC OF LETTERS: A QUALUNQUE COMMUNITY OF LITERATURES
}

Recommended Citation: Karaman, Hatice. "Reconsidering The World Republic of Letters: A Qualunque Community of Literatures”. Metacritic Journal for Comparative Studies and Theory 7.2 (2021). Doi: https://doi.org/10.24193/mjcst.2021.12https://doi.org/10.24193/mjcst.2021.12.07. 06

\begin{abstract}
In the preface to the English edition of The World Republic of Letters, Pascale Casanova focuses on the existence of a literary world/universe, which maintains a relative autonomy from the world and its political disparities and restrictions. This suggested ideal of a literary space is an attempt to posit world literature as an alternative chronotope in which literary production can survive and multiply transnationally. My paper will offer a reconsideration of this global literary space, read via a philosophical perspective, shaped by the famous discussion of the common and community as conducted by Giorgio Agamben, Maurice Blanchot, Georges Bataille, among others. Within the above theoretical frame, my attempt will be to reread Casanova's contribution to World Literature as a desired community of literature(s), formed by the coming together of qualunque singularities which coexist and co-belong without "any representable condition of belonging" (Agamben). Furthermore, the idea of qualunque (whatever) will constitute the starting point for the ethico-political reconsideration and reconceptualisation of the global literary space offered by Casanova, not only without borders but also without hierarchies.
\end{abstract}

Keywords: world literature, comparative literature, literary theory, philosophy of literature, whatever singularity 


\section{Introduction: The Problem of the Name}

What crisis? Was it foreseeable or unforeseeable? And what if the crisis even concerned the very concept of crisis or of critique? (Jacques Derrida, On the Name)

In Tradition of the Immemorial, Agamben discusses the problem of presupposition, which is inherent within language, claiming that "discourse cannot say what is named by the name" (Agamben 1999, 107). There is a certain paradox in naming, and therefore in discourse, caused by the presupposition of signification. The name itself is a marker of this paradox, being "the linguistic cipher of presupposition, of what discourse cannot say but can only presuppose” (Agamben 1999, 107, 108). Within the contemporary framework of literary studies in the age of globalism, many theorists have emphasised the relevance of proper naming. The search for a proper name and a definition has always been vital, since the name would not only define but also determine the scope, the limits, and the domain of the work of literature. The attempt to discuss the relationship between a definition and a limit may very well be initiated with Heidegger's reading of Aristotle's concepts:

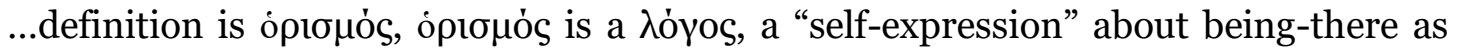
being. Opıouós is not a way of apprehending through sharp determination, but rather the specific character of opıouós ultimately arises from the fact that the being itself is determined in its being as circumscribed by the $\pi \dot{\varepsilon} \rho a \varsigma$. Being means being-completed (Fertigsein) $^{1}$ (Heidegger 11).

The problem of naming and definition is indeed a problem, one that is always related to the issue of constructing limits and borders. Since the act of naming as an act of construction is necessarily an act to be undone and redone, deconstruction and reconstruction also pertain to this very act. Accordingly, the major intention of this article is firstly to interrogate the question of the name, and secondly to try to clarify the bond between nomination, language, and community. Within this framework,

${ }^{1}$ Author's emphasis. 
this attempt will offer a rereading of Pascale Casanova's Republic of Letters, from an ethico-political standpoint, taking into consideration the queries regarding naming.

\section{The Inherited}

Johann Wolfgang von Goethe has always been credited with positing the idea of "Weltliteratur" as the coming-literature of modern times. Although recent discoveries suggest that A. Ludwig von Schlözer coined the term in 1773 (Habjan 398), Goethe has been indicated and accepted as the foundational name in this regard, in literary criticism or comparative literature in general. David Damrosch, for instance, one of the most prominent scholars in the field, starts his work What Is World Literature? with a quotation from Eckermann's Conversations and thus provides us with his own account regarding the phenomenon:

I take world literature to encompass all literary works that circulate beyond their culture of origin, either in translation or in their original language (Virgil was long read in Latin in Europe). In its most expansive sense, world literature could include any work that has reached beyond its home base... (Damrosch 2003, 4)

The name in the discipline of literature(s) or comparative literature tends to be associated with Goethe's Weltliteratur, which was later emphasised by Marx and Engels. In the historical development of the concept, some sub-concepts, such as comparative literature, international, transnational, canonical, subcanonical, minor literature, etc. kept proliferating, with specific focus on the idea of a "global literary market”. Ever since Goethe, Marx, and Engels, the association of world literature with the global market, in other words a global economy, has been inevitable. Thus, the issue of being acknowledged as "world literature" is strictly circumscribed by the limitations of translation which in its turn is mostly determined by the publication market. The alternative is the market of literary criticism that in itself is bounded by the economy of literary criticism, which is (pre)determined by the publication economy. This double bind can still be transgressed, and it can lead to an expansion of what is called world literature. The boundaries, the borders between national and international literatures are frequently dissolved via the works of literary critics and scholars: 
Scholars are always seeking to intervene in the academic marketplace and ultimately to influence a wider public, directing attention to neglected authors, texts, and approaches. Comparatists in particular tend to have an oblique, or we might say transversal, relationship to national markets. We often aggregate and value writers differently from their usual ordering within the national canon, and we press our specialist colleagues to open out more fully to the international dimensions within and beyond their borders. Both the national and the international literary canons are constantly shifting, as a result of changing tastes as well as scholarly interventions (Damrosch 2020, 223).

As Emily Apter pertinently indicates, multiple issues related to "the importance of non-translation, mistranslation, incomparability and untranslatability" remain unresolved to this day (Apter 19). Nonetheless, the very act of comparative literature contributes to the expansion of its content, together with literary theory, criticism, and translation, despite the ongoing debates which target the latitude of Weltliteratur. The concerns regarding American/European domination and centralisation maintain their relevance to this very day. The eternal return to the discourse of a market and an economy has also been underscored by Bogdan Ștefănescu, who associated comparison itself with buying and commodification, with reference to the verb's etymology (Ștefănescu 24, 25). The connection between Weltliteratur and Weltmarkt, stressed as it is via the etymological roots of comparing seems inevitable. Highlighting the marketing aspect of the idea, Ștefănescu discusses the implausibility, if not the impossibility of equality in a hypothetical community of world literature:

The way things still stand today, comparisons between Western and Eastern literatures, cultures or societies are posited in the mind of most comparatists as putting side by side the original and its various copies or derivatives. Under the circumstances, attributing value and ranking the Western original over an Eastern copy is the prearranged and unavoidable market outcome (Ștefănescu 26).

It appears that discussions about the name and the extent of the field are unlikely to reach an acceptable conclusion in the near future, since the inherited problem of naming is closely related to the criteria of what is called world literature and what is "not" world literature. 
Each year new publications come out with the aim of relocating neglected authors, literary works, and national literatures in the international canon. The series Literatures as World Literature by Bloomsbury is one of the many examples of the effort to map different genres and national literatures as part of world literature; prominent titles in the series include, for instance, Romanian Literature as World Literature (2019), Bulgarian Literature as World Literature (2020) and Turkish Literature as World Literature (2021). These examples help to fill a gap in international and transnational readings in literature, while, ironically, making the tautology of naming visible. What literature is Turkish/Bulgarian/Romanian Literature when it is not re-called "world literature"? The inherited name and all its associations with the limitations of a market leave the scholars of literary studies with an aporetic legacy to be confronted, but also with a father to be killed, so that anxiety can be dissolved. Invaluable attempts at overcoming borders, boundaries, linguistic and translatability restrictions remain trapped in the opıouós, in the very definition which cannot be defined without explicating the name together with the inheritance. For this reason, this paper focuses on the problem of nomination in the field of world literature, by reconsidering the name with its constructive and formative power. The theoretical framework for the argument is provided by Giorgio Agamben's reflections on the paradoxical aspects of naming and community with reference to the ontological determination of human beings as speaking beings, which immediately calls for ethics and politics. ${ }^{2}$ In the following part, I will offer a reading of Casanova's coinage, the republic of letters as a literary universe, connecting it with the debate on community shaped around the question of a new conception of community, which has flourished especially since the fall of communism. While the debate has had several contributors such as Georges Bataille, Jean Luc Nancy, Jacques Derrida during the 1980 s and 1990s, I will pay specific attention to the work of Blanchot and Agamben in accordance with the scope of the present study.

\footnotetext{
2 The Aristotelian determinations of the human being as "zoon logon ekhon" and "zoon politikon" become more intermingled, indeed inseparable in Heidegger's reading, playing a definitive role in the development of his ideas on Dasein and Sein. Therefore, the emergence of the ideas in Sein und Zeit can be traced back to his reading of Aristotle's concepts in Basic Concepts of Aristotelian Philosophy (2009), a collection of his 1924 Marburg Lectures. In Heidegger's account, the distinction between ontology and ethics/politics gets blurred. It could be argued, especially following Levinas's positing of ethics as prote philosophia, that these determinations are strictly ethico-political, in contrast with their general categorisation as ontology.
} 


\section{The World Republic of Letters Or The World of Lovers}

Since 1999, Casanova's contribution to the field has been almost unmatched. The World Republic of Letters offered a new perspective which clearly approaches global literature not only as a literary space but also as a community. Arguing for a world republic of letters as an international literary space instead of world literature, Casanova patently shifted the path of thinking about world literature towards a more strictly political and hence a communal one. The major purpose of the book was to posit a literary universe separated from the daily world and independent from real politics to a certain degree. For this, Casanova employed a wide variety of philosophical and scholarly references, from Spinoza to Valery Larbaud, who underscored the significant differentiation between the "political map" and the "intellectual map" (Casanova 10). Casanova emphasised the shifting nature of literary centres, capitals and the rivalry among them as builders of world literature. The capitals of literature are cities or countries in which a literary and cultural accumulation takes place which dominates the universal literary space, while at the same time crossing national borders and restrictions. In her words:

As against the national boundaries that give rise to political belief and nationalist feeling, the world of letters creates its own geography and its own divisions. The territories of literature are defined and delimited according to their aesthetic distance from the place where literary consecration is ordained. The cities where literary resources are concentrated, where they accumulate, become places where belief is incarnated, centers of credit, as it were (Casanova 23).

Casanova pointed at different literary centres, changing, although slowly, from Renaissance Italy to France. Recalling Larbaud, Casanova suggests that literary critics and professionals, as members of an invisible society which decides on what is literary, are the principal actors of the movement from the national to the international literary space (Casanova 22). According to her, literary critics determine the literary value of a text, while "rescuing texts from imprisonment within literary and linguistic boundaries, they lay down autonomous - that is, nonnational, international - criteria of literary legitimacy" (Casanova 22). By this, Casanova pictured an alternative universe for literature and its evaluation, which is autonomous in its mobilisation and development. This autonomy amounts to an independence from the domination of historico-political hegemonies as much as to 
inter-social, inter-cultural determinations of global affairs. Hence, the politics of literature is portrayed as relatively isolated from ordinary politics and its power relations.

Casanova acknowledged the connotations between Weltliteratur and Weltmarkt, following Goethe, Valéry, and Berman. Therefore, she selected Paris as a prominent literary centre and homeland, and collocated it with references to "the capital" as marketplace: "thus Ramuz described Paris as «the universal bank of foreign exchange and commerce» in literature" (Casanova 24). Paris is the literary capital due to its atmosphere of political freedom and its historical background as a place of revolution: "By its ability to convert great political events into literature, Paris further strengthened belief in its preeminent position as the capital of the literary world" (Casanova 26). The atmosphere of political liberty and the gathering of different authors, translators, and theorists from different parts of the Earth contributed to the literary and intellectual fame of the city as a microcosmos of letters, "a miniature version of the world" (Casanova 26). Thus, the idea of community behind the republic of letters as a global independent literary community finds its capital in Paris, not only figuratively but also literally.

Casanova's reflections on Paris and its propriety for the enrichment of literary and intellectual circulation are remarkable. Nevertheless, in her account, the plurality and inclusiveness implied in the idea of a universal space of literature as a world republic of letters are paradoxically captured in one centre. Although Casanova argues that Paris is the locus for de-nationalisation and internationalisation, Paris becomes - in theory and practice - the new centre of the republic. The attempt to enlarge the tent of the discipline according to the margins of internationalism does not demand a new centre; on the contrary, it demands "a view from nowhere".3 Additionally, despite its initial claim of describing the literary world independently from ordinary power relations, with its own rivalries, struggles, and inequalities, the discourse of depictions regarding the republic does not acquire a different character than that of real politics and economics, underscored by all the incumbent allusions to the Weltmarkt:

\footnotetext{
3 In The View from Nowhere (1989), Thomas Nagel investigates the possibility of integrating objectivity and subjectivity, relocating the subjective standpoint within objectivity, while disclosing how objectivity stems from and via the subjective perspective of an individual. By suggesting such a perspective as a "view from nowhere", he seeks a sort of objectivity in which the singular perspective, or subjectivity is not entirely lost.
} 
The belief in the power of the capital of the arts is so strong that not only do artists throughout the world unreservedly accept the preeminence of Paris; owing to the extraordinary concentration of intellectual talent there that follows from this belief, Paris has become the place where books - submitted to critical judgment and transmuted - can be denationalized and their authors made universal. By virtue of its status as the central bank of literature, to revert to the terms employed earlier, Paris is able to create literary value and extend terms of credit everywhere in the world (Casanova 127).

As stated earlier, Casanova's world republic of letters as an alternative universe or an autonomous literary space regulated by its own rules, especially via literary criticism and theory, opens a path for an ethico-political discussion with a specific emphasis on the "communal" aspect. This change of perspective also offers a shift from an epistemological discussion of world literature to an ethical and political one. The boundary that is set by Casanova herself in stating this differentiation from daily politics and power relations leaves a lacuna which encourages a reconsideration of the community of literature, its politics and discourse, starting with the problems of its nomination.

Casanova's admiration for the cultural aura of Paris is reminiscent of Maurice Blanchot's similar appreciation. Although Blanchot does not name Paris as such, his incisive awareness of the importance of the events of May 1968 pertains to a similar judgment on the literary and intellectual fecundity provided by the French capital:

May '68 has shown that without project, without conjuration, in the suddenness of a happy meeting, like a feast that breached the admitted and expected social norms, explosive communication could affirm itself (affirm itself beyond the usual forms of affirmation) as the opening that gave permission to everyone, without distinction of class, age, sex or culture, to mix with the first comer as if with an already loved being, precisely because he was the unknown-familiar (Blanchot 29-30).

For Blanchot, this chronotope was a time of inflated communication and literary production where "poetry was an everyday affair" (Blanchot 30). In The Unavowable Community, he elaborates on the issue of community by making references to Jean Luc Nancy's Inoperative Community and Georges Bataille's Acéphale, the literary community of those who do not have a community. Bataille's understanding of a 
community in Acéphale was a negative one, primarily because it was based on sacrifice. Secondly, as Blanchot claims, since Bataille's approach to the exigency of a community arose from his negative conception of the human being, this translated into an existing insufficiency or incompleteness in being (Blanchot 5). Although negative, Bataille's ideas contributed to the discussion on the subject of a community of equals, a community without a central authority. Following the idea of a community without a central commonality, Blanchot romantically suggested a "community of lovers" in which the subjects dissolve into a mysterious dissymmetry, thus recalling Levinas's concentration on the ethical relationship with the Other. Blanchot also reinforces the significance of this ethical responsibility and obligation towards the other and associates it with the relationship between death and love, as in the case of Tristan (Blanchot 44). As Levinas proposes in Totality and Infinity, "a non-allergic relation with alterity" is to be construed in discourse "in the society of the I with the Other - language and goodness" (Levinas 47).

Like Bataille's, Blanchot's account of the community cannot evade negativity, since his conception of love is necessarily linked with death. That is why the idea of a community of lovers becomes the unavowable community. Nevertheless, Blanchot's thoughts on this uncanny understanding of the community that is associated with love and communication allows for further elaboration:

Wittgenstein's all too famous and all too often repeated precept, "Whereof one cannot speak, there one must be silent" - given that by enunciating it he has not been able to impose silence. on himself - does indicate that in the final analysis one has to talk in order to remain silent. But with what kinds of words? That is one of the questions this little book entrusts to others, not that they may answer it, rather that they may choose to carry it with them, and, perhaps, extend it. Thus, one will discover that it also carries an exacting political meaning and that it does not permit us to lose interest in the present time which, by opening unknown spaces of freedom, makes us responsible for new relationships, always threatened, always hoped for, between what we call work, oeuvre, and what we call unworking, desoeuvrement (Blanchot $56)$.

Blanchot's depiction of May 1968 or the literary community of Paris involves an emphasis on spontaneity. The togetherness that fascinates Blanchot is, as mentioned before, without project and conjuration. It is the unique experience of pure 
communication of literature, theory, and philosophy, like an assemblage without a hinge. It involves conjoining without joint. For him, May 1968 shows the possibility of a community in which there is no centre, in which "everybody had something to say, and, at times, to write (on the walls); what exactly, mattered little. Saying it was more important than what was said" (Blanchot 30). Pure communication, when the transmission becomes more significant than the transmitted, enables the possibility of a "headless" society, a society of equals. According to Blanchot, the community is not a place of sovereignty (Blanchot 12); instead, the community takes place in its own taking place without being founded by or via someone on the basis of some defined commonality. These ideas regarding community, whether one calls it a community of lovers or a literary community, as developed by Blanchot remain inspiring but are not clearly initialised. Both Bataille and Blanchot carry the discussion to the linguistic sphere, the former through a consideration of a writing society and the latter by emphasising the significance of spontaneous communication.

In The Coming Community, however, Giorgio Agamben takes up the discussion from where it is left by Bataille, Nancy, and Blanchot. Agamben's investigation of the problem of commonality, which is arguably a significant corollary of his earlier work on language and philosophy, is illuminating. The Coming Community suggests a type of community which is not constructed around a centralised common identity or belonging. While discussing a community without a definitive common identity, Agamben also focuses on singularities. His project intends to argue for the preservation of singularity within the community. Therefore, Agamben traces the possibility of a community in which the singularity remains, and which contains its uniqueness. Similar to Blanchot's reference to love and lovers, Agamben offers lovability (quodlibet) with "whatever singularity" as a non-criterion for a community, with reference to the Medieval problem of the universals. His explanation of "whatever" as signifying that it always matters rather than meaning "it does not matter" provides Agamben with a positive ground to redefine community:

The coming being is whatever being. In the Scholastic enumeration of transcendentals (quodlibet ens est unum, verum, bonum seu perfectum - whatever entity is one, true, good, or perfect), the term that, remaining unthought in each, conditions the meaning of all the others is the adjective quodlibet. The common 
translation of this term as "whatever" in the sense of "it does not matter which, indifferently" is certainly correct, but in its form the Latin says exactly the opposite: Quodlibet ens is not "being, it does not matter which", but rather "being such that it always matters" (Agamben 1993, 1).

The Latin quodlibet has its etymological kinship with libet that implies will and desire, hence love. In the Scholastic context, one attribute of "being" is indifferent lovability. "Whatever being has an original relation to desire" (Agamben 1993, 1). Agamben's concept of whatever, then, intends to deconstruct the determination of any singularity by a common property. A whatever singularity cannot be determined by being red, French, or Muslim, as Agamben exemplifies; but by its being such as it is. Considering the singularity as whatever singularity indicates not belonging to a class, a set, a genus, or species but a deprivation of belonging, or a belonging to self. According to Agamben, a singularity which is born or defined in this way is lovable. Therefore, he explains that love does not specifically focus on particular properties of the loved one, instead it desires all its properties. In other words, love wants the loved one as it is. Being-as-such, being whatever singularity is a key term for the coming community that is contemplated by Agamben.

In the chapter titled Example, he introduces another very important aspect of the coming community. Here, the exemplary being and/or linguistic being is the main focus. The word tree signifies all trees "indifferently" (Agamben 1993, 9). This means that it designates singularities as members of a class which requires belonging. Then, the meaning of the word is defined by a common property. As Agamben points out, the example escapes the antinomy between individual and universal. That is to say, the example is a singularity which contains all circumstances related to a type and at the same time it is contained among them. In other words, it is a singularity that "stands for each of them and serves for all" (Agamben 1993, 10). The linguistic being refers to being-called. It is both the set or universal and the singularity (or the individual). It belongs to itself but at the same time to the class. Therefore, the example is a linguistic being. It is the example of a particular case, but it cannot be proper to a certain case only. It is neither universal nor individual but a singularity which exposes itself such as it is. That is why the life of the example is purely linguistic and cannot be defined with any property or identity. It can merely be known as being-called. For Agamben, being-called leads to 
the questionability of possible belongings, although it is the one that establishes them all. Being-called implies ambiguity, indeterminacy and overcomes substantiality. Thus, the possibility of whatever-being should replace the "Most Common" in the community that disrupts it the most (Agamben 1993, 10). According to him, this constitutes the powerless or non-authorial value of whatever-being. The exemplars are, for this reason, the whatever beings of the coming community; as pure singularities which are not limited, defined, or determined by identities or common properties. The reconsideration of the example as purely linguistic being, that is being-called, enables the dissolution of identifications such as being Italian, being Turkish, being European. Instead, it directs emphasis on the insubstantiality of these identities or terms by suggesting a solely linguistic being. In this way, it is argued that the concepts or properties that make a centre for the constitution of the common are not absolute qualifications. The distinction between being Turkish and being-called Turkish becomes the major concern for rethinking the singularities, and hence the community.

The problematisation of being-called is not only significant within the context of the community discussion, but also for the problematisation of the name. The proximity between being-called and the name is worth considering. Moreover, Agamben's writings on language shed light on the path that leads him to whatever being and the common-less community. In the collection of essays published in English in 1999 under the title Potentialities, Agamben's criticism and reflections on the problems of language, unsayability, potentiality, and the im-potentiality of language are presented as a preconditional discussion for any further investigation on ethics and politics. The presuppositions inherited by speaking beings within linguistic history are positioned as the barriers in-between the speaking being and language, which is the condition for communicability:

For if politics concerns itself, as Agamben writes, "not within a state, but with an event of language", if politics has to do "not with one grammar or another, but with a factum loquendi as such", then to interrogate this factum - "to read what was never written" - is also to reflect on what it means to be "the political animal", as Aristotle said, precisely in being "the animal that has language". And to examine the pure existence of language, freed from the form of any presupposition, is to consider a community inconceivable according to any representable condition of belonging: a "coming community", without identity, defined by nothing other than its existence in 
language as irreducible, absolute potentiality (Heller-Roazen 23).

In Potentialities, Agamben's approach to language is constructed primarily upon his readings of Plato's Seventh Letter and Aristotle's On Interpretation, together with the writings of Benjamin, Kommerell, Milner, and Derrida. It is beyond the scope of the present study to elaborate on these arguments, yet it is necessary to explain that Agamben's commentary points towards a sort of "original position" 4 within language with its attempt to deconstruct presuppositions, namely names: "The name already belongs to a paradoxical term since the name cannot name itself: to name the name, I will no longer be able to distinguish between word and thing, concept and object, the term and its reference" (Agamben 1996, 213). The act of nomination itself is aporetic. The name does not take place as a name before being the name of something. It is there as potentiality, to take place and to expose itself in action, similar to Blanchot's description of the community: "It is what exposes by exposing itself" (Blanchot 12).

\section{A Carnivalesque Community of Letters?}

'We have read your novel' said Woland; turning to the master, 'and we can only say that unfortunately it is not finished...'

(Bulgakov 357)

When is a novel finished? Or a poem? When and where does a work of literature become one? How does a literary work - if literary - become world literature? Which literature is not world literature? Translation, international recognition, commonality, or parallelism of imagery and representation are among the most prominent criteria of categorisation. Yet one of the most preeminent intentions of designating a Weltliteratur has always been to either extend or demolish borders to

\footnotetext{
4 Here the idea of an original position is recalled with reference to John Rawls's A Theory of Justice (1999). The original position is suggested by the theorist as a point of origin before a social contract in which the representatives of the occuring community are under a veil of ignorance. The principles of justice are thought to be accepted by free and rational persons in a hypothetical initial position, as the basis for a well-ordered society and its institutions. In the original position Rawls imposes some restrictions of knowledge on the parties in order to ensure that the agreements are fair. The original position "is a state of affairs in which the parties are equally represented as moral persons and the outcome is not conditioned by arbitrary contingencies or the relative balance of social forces" (Rawls 104).
} 
achieve a literary international. All these epistemological approaches within the project have contributed to this noble intention.

Both translation studies and World Literature extended the promise of worldly criticism, politicized cosmopolitanism, comparability aesthetics galvanized by a deprovincialized Europe, an academically redistributed area studies and a redrawn map of language geopolitics (Apter 25).

Nevertheless, as Apter further discusses, together with the new crises in the humanities, both world literature and translation disciplines still fall behind their targets (Apter 26). Therefore, the demand for further discussion remains solid. As discussed before, Casanova's work has provided us with an alternative literary space for the transmission of the national to the international. Paris, the cultural capital according to Casanova, has achieved such multinationality. And yet, Casanova's terminology followed a commercial discourse, the economy of criticism and the criticism of the economy. On the other hand, Blanchot's perception of the literary fecundity of May 1968 as "carnivalesque" (Blanchot 31) knowingly or unknowingly revived Bakhtin's work on the carnival and heteroglossia.

Carnival is not a spectacle seen by the people; they live in it, and everyone participates because its very idea embraces all the people. While carnival lasts, there is no other life outside it. During carnival time life is subject only to its laws, that is, the laws of its own freedom. It has a universal spirit; it is a special condition of the entire world, of the world's revival and renewal, in which all take part. Such is the essence of carnival, vividly felt by all its participants (Bakhtin 7).

The Bakhtinian description of the carnivalesque coincides with the idea of a community without sovereignty and a community of whatever beings in more ways than one. The carnival exposes itself via exposing itself, in a similar manner to Blanchot's definition of community. It is something that people participate in by taking place without exception, as in Agamben's depiction of co-existence via communication. "Taking-place, the communication of singularities in the attribute of extension, does not unite them in essence, but scatters them in existence" (Agamben 1993, 18). The carnival has its own rules which can be associated with Casanova's initial design of an independent, autonomous literary universe; moreover, "the 
carnival enables liberation from the prevailing truth and from the established order; it marked the suspension of all hierarchical rank, privileges, norms, and prohibitions" (Bakhtin 10). The carnival participants are Agamben's exemplary beings who come together merely in their whateverness, being as such and lovability. "They are expropriated of all identity, so as to appropriate belonging itself, the sign $\varepsilon$. Tricksters or fakes, assistants or 'toons, they are the exemplars of the coming community" (Agamben 1993, 11).

If one is to reconsider a world republic of letters, following Casanova, dwelling on the problem of language is of utmost importance. Literature allows us to talk about it, on it, within itself and within language. Literature is pure being-in-language and does not necessarily ask for specific discourses involving epistemological categories, publication data, or sales graphics. The circulation of literature is pure communication among communities and generations. Whatever literature is lovable. "Quodlibetality" which is neither indifference nor a "predicate of singularity that expresses its dependence on common nature" can guide our reflections on the ideal of a global space of literature (Agamben 1993, 17).

\section{Conclusion}

Acknowledging the need for every genre of discussion in the field of world literature and focusing on different aspects of literature as a market, as an economy which is not easily separated from the challenges and ordeals of everyday politics and the world, this study opted for an ethico-political reconsideration, inspired by Casanova's account. The community of letters has been read in a framework which juxtaposes Casanova's literary universe with a discussion on a potential or even ideal community of equals. A discourse on such a community requires care for the singularity within plurality, hence it also needs to be an ethical investigation. Since ethics and politics, like literature itself, take place as relations within language, this brief study attempted to explore some linguistic problems, especially regarding the aporetic character of nomination and its constitutive capacity: "Anything we name or conceive of is already somehow pre-supposed in language and knowledge by reason of the simple fact of being named" (Agamben 2018, 3). Accordingly, the community discussion has been supported by references to Agamben's approach, especially in view of his constant, dedicated involvement with language-related issues: "In the definition according to which man is the living being that has language, the decisive 
element is clearly not life, but language" (Agamben 2018, 2). In addition, I posited Agamben's representation of a whatever community as a more open, flexible solution to solving the conundrum of world literature studies, in view of its potential eligibility as a basis to imagine a carnivalesque universe of polyphony. For this, I have attempted to draw attention to the difficulties of naming together with the problematic relationship between human beings and their procrastinated relationship with language in its presupposing character. If literature or the community of qualunque literatures is to attain any eternal life within universal time and space, in history and the world, that is within language.

\section{References:}

Agamben, Giorgio. The Coming Community. Trans. Michael Hardt. Minnesota University Press, 1993.

Agamben, Giorgio. Potentialities: Collected Essays in Philosophy. Edit. \& Trans. Daniel Heller-Roazen. Stanford University Press, 1999.

Agamben, Giorgio. What is Philosophy? Trans. Lorenzo Chiesa. Stanford University Press, 2018.

Apter, Emily. Against World Literature: On the Politics of Untranslatability. Verso, 2013.

Bakhtin, Mikhail. Rabelais and His World. Trans. Helene Iswolsky. Indiana University Press, 1984.

Blanchot, Maurice. The Unavowable Community. Trans. Pierre Joris. Station Hill Press, 1988.

Bulgakov, Mikhail. The Master and Margarita. Trans. Michael Glenny. Penguin, 2003.

Casanova, Pascale. The World Republic of Letters. Trans. M.B. DeBevoise. Harvard University Press, 2004.

Damrosch, David. What is World Literature? Princeton University Press, 2003.

Damrosch, David. Comparing The Literatures: Literary Studies in a Global Age. Princeton University Press, 2020.

Derrida, Jacques. On The Name. Trans. Thomas Dutoit. Stanford University Press, 1995 . 
Habjan, Jernej. "The global process of thinking global literature: from Marx's Weltliteratur to Sarkozy's littérature-monde”. Journal of Global History, Vol. 14, no. 3, 2019: 395-412, DOI: 10.1017/S1740022819000184.

Heidegger, Martin. Basic Concepts of Aristotelian Philosophy. Trans. Robert D. Metcalf \& Mark B. Tanzer. Indiana University Press, 2009.

Levinas, Emmanuel. Totality and Infinity: An Essay on Exteriority. Trans. Alphonso Lingis. Martinus Nijhoff Publishers, 1979.

Nagel, Thomas. The View From Nowhere. Oxford University Press, 1989.

Rawls, John. A Theory of Justice: Revised Edition. Harvard University Press, 1999.

Ștefănescu, Bogdan. "Why Compare? What's To Compare? The Practice of Comparative Literature in a Postcolonial/Postcommunist Context. A Response to David Damrosch”. University of Bucharest Review, Vol.1, no. 1, 2011, pp. 21-28. 